\title{
L-Ornithine Aspartate - a Rationale for Its Use in Combination with Chemotherapy, Radiation, and Hyperthermia in Oncology
}

L-ornithine aspartate has been widely used in hepatology for its well-known effects on lowering blood ammonia concentrations by increasing urea synthesis [1]. Moreover, accumulating evidence suggests that L-ornithine aspartate restores muscle protein synthesis, an effect which can be exploited in patients suffering from cancer or HIV infections [2].

Other studies showed significant improvements of clinical values and liver function in patients undergoing radiation therapy receiving L-ornithine aspartate [3]. Furthermore, L-ornithine aspartate increased the tolerance towards cytostatic drugs in patients receiving chemotherapy [4]. In this study with 157 patients the chemotherapy-induced increase in liver transaminases could be limited, whereas the production of cholinesterase as parameter for liver function could be increased in patients receiving L-ornithine aspartate parallel to chemotherapy with antimetabolites, platinum derivatives, alkylating agents, anthrazyklines, and mitosis-inhibiting substances. Chemotherapy is known to induce transient states of hyperammonemia [5].

The hypothesis is put forth that L-ornithine aspartate also may have a protective effect on proliferation kinetics of tumor cells. Recently, ammonium cholate has been shown to accelerate the growth of the MCF-7 cell line in vitro, an effect which may be blocked by the administration of L-ornithine aspartate [6]. Ammonia has been shown to be associated with increased metastasis [7] as well as anorexia and showed a rise in activity, following the ad- ministration of intravenous injections of ${ }^{13} \mathrm{~N}$-labelled ammonia in different tumor types. Ammonia also is involved in the regulation of protein turnover in tumor cells. L-asparagine synthetase has been suggested as a marker for metastases. Moreover, in multiple myeloma growth has been allied with hyperammonemia [8]. This hyperammonemia could be demonstrated not to be due to liver dysfunction but to increased production of ammonia by myeloma cells. Furthermore, progressive malignant growth in tumor-bearing animals correlated with increased ammoniagenesis and increased glutamine uptake in other tumor tissues and the liver [9].

The hyperthermic treatment of cancer also induces high levels of ammonia in the tumor environment [10], indicating increased proteolysis reflected in the rise in urea.

Taken together these findings indicate that conventional cancer treatments such as chemotherapy and radiation together with hyperthermia are associated with a rise in the levels of ammonia both in the blood stream and the tumor microenvironment. On the other side, ammonia may function as a mediator for local tumor growth and metastasis. Hence, further experimental and clinical studies are indicated to investigate the potential of the administration of L-ornithine aspartate as an adjunct to standard cancer treatment regimens.

R. Kleef, Wien

A. Scheller, Kornwestheim

\section{References}

1 Staedt U, Leweling H, Gladisch R, Kortsik C, Hagmuller E, Holm E: Effects of ornithine aspartate on plasma ammonia and plasma amino acids in patients with cirrhosis. A double-blind, randomized study using a four-fold crossover design. J Hepatol 1993;19:424-430.

2 Reynolds N, Downie S, Smith K, Kircheis G, Rennie MJ: Treatment with L-ornithine aspartate (LOLA) infusion restores muscle protein synthethis responsiveness to feeding in patients with cirrhosis. J Hepatol 1999;30(suppl 1):1999.

3 Kuttig H: Verbesserte Toleranz grossvolumiger abdomineller Strahlentherapie durch Ornithinaspartat. Therapiewoche 1983;33:3495-3511.
4 Scheller A, Jacob U, Keilhauer R, et al: Verbesserung der Zytostatikatoleranz durch Ornithinaspartat. Der Bayrische Internist 1998;1:54-60.

5 Liaw CC, Liaw SJ, Wang CH, Chiu MC, Huang JS: Transient hyperammonemia related to chemotherapy with continuous infusion of high-dose 5-fluorouracil. Anticancer Drugs 1993;4:311-315.

6 Mappes L: Testung von Cholsäure auf Proliferation von Carcinomzellen. Unpublizierte Laborstudie, Endometrium-Labor, Universität Tübingen, 1998.

7 Leibovici L, Schoenfeld N, Yehoshua HA, Mamet R, Rakowsky E, Shindel A, Atsmon A Activity of porphobilinogen deaminase in peri- pheral blood mononuclear cells of patients with metastatic cancer. Cancer 1988;62:2297-3000.

8 Otsuki T, Yamada O, Sakaguchi H, Ichiki T, Kouguchi $\mathrm{K}$, Wada H, Hata H, Yawata Y, Ueki A: In vitro excess ammonia production in human myeloma cell lines. Leukemia 1998;12:1149-1158.

9 Chen MK, Espat NJ, Bland KI, Copeland EM III, Souba WW: Influence of progressive tumor growth on glutamine metabolism in skeletal muscle and kidney. Ann Surg 1993;217:655-666, discussion 666-667.

10 Jacob S, Holm E, Fischer B: Effects of hyperthermia on the peripheral metabolism of ammonia and glutamine. Metabolism 1989;38(suppl 1):43-46.

\section{KARGER}

Fax +497614520714

E-mail kargergmbh@aol.com

www.karger.com 